\title{
Bark decomposition in white oak soil outperforms eastern hemlock soil, while bark type leads to consistent changes in soil microbial composition
}

\author{
Rondy J. Malik (iD) Ryan V. Trexler • David M. Eissenstat • Terrence H. Bell
}

Received: 12 November 2019/Accepted: 7 September 2020/Published online: 18 September 2020

(C) The Author(s) 2020

\begin{abstract}
Bark decomposition is an underexamined component of soil carbon cycling and soil community assembly. Numerous studies have shown faster decomposition of leaf litter in "home" environments (i.e. within soil adjacent to the plant that produced the leaves), suggesting potential legacy effects from previous deposition of similar litter. This is expected to occur through, in part, accumulation of microorganisms that metabolize substrates the litter provides. Whether a similar "home-field advantage" (HFA) exists for bark decomposition is unknown, but this dynamic may differ because annual bark deposits to
\end{abstract}

Responsible editor: Karsten Kalbitz.

Electronic supplementary material The online version of this article (https://doi.org/10.1007/s10533-020-00701-7) contains supplementary material, which is available to authorized users.

R. J. Malik $(\varangle) \cdot$ D. M. Eissenstat

Department of Ecosystem Science and Management, Penn

State University, University Park, PA 16802, USA

e-mail: rjmalik@ku.edu

R. J. Malik · R. V. Trexler · T. H. Bell

Department of Plant Pathology and Environmental

Microbiology, Penn State University, University Park,

PA 16802, USA

\section{R. J. Malik · D. M. Eissenstat · T. H. Bell}

Huck Institutes of Life Sciences - Intercollege Graduate

Degree Program in Ecology, Penn State University,

University Park, PA 16802, USA soil are minimal relative to leaf deposits. We hypothesized that (1) as with leaf litter, bark will be better decomposed near to the tree from which it was collected, and (2) that decomposing bark can initiate change in soil microbial composition. To test these hypotheses, we used a full factorial design that included two bark types (collected from eastern hemlock, Tsuga canadensis, and white oak, Quercus alba) and two soil types ('home' and 'away') within a temperate mixed hardwood forest at the Shale Hills Catchment in central Pennsylvania, USA. Bark was excised from 25 replicates of each tree type, buried in either home or away soil, and incubated belowground from July 2017 to June 2018. Decomposition was assessed through proportionate mass loss over time, while microbial composition in the bark and adjacent soil was assessed through high-throughput sequencing of 16S rRNA gene and fungal ITS fragments. Overall,

Present Address:

\section{R. J. Malik}

Department of Ecology and Evolutionary Biology, and Kansas Biological Survey, The University of Kansas, Lawrence, KS 66045, USA 
bark degraded faster in white oak soils, and there was also an effect of bark type on decomposition. Although white oak bark decomposed more quickly in its home environment, this could be due to either soil conditioning or inherent differences in the soils in which each species grows. Soil microbial assemblages also sorted according to bark type rather than soil type, suggesting that bark strongly influences the composition of nearby microorganisms during decomposition. Our results suggest that both bark type and soil type are important factors during bark decomposition, but our findings suggest no clear evidence for HFA.

Keywords Home-field advantage (HFA) . Decomposition · Bark - Temperate forest - Eastern hemlock $\cdot$ White oak $\cdot$ Microbial ecology $\cdot$ Ecosystem ecology

\section{Introduction}

Nutrient mobilization is essential to life on earth (Read and Perez-Moreno 2003; Treseder and Lennon 2015, Bardgett 2016). Decomposition recycles organic material to structure soils, sequester carbon, and shape trophic interactions (Cebrian 1999; Gessner et al. 2010; Matulich and Martiny 2015). Numerous microbial functional groups possess the enzymatic machinery to contribute to decomposition (Swift et al. 1979; Wall and Moore 1999; Waldrop and Firestone 2004; d'Annunzio et al. 2008; Wei et al. 2009; Shah et al. 2016), but the relationship between microbial composition and nutrient cycling in soils likely depends on the quality, identity, quantity, and frequency of deposited organic materials (Li et al. 2019; Glassman et al. 2018; Chapman et al. 2013; Zeng et al. 2017). In woodlands, dead plant material first encounter soil communities as litter. Litter introduction, including leaves, roots, stems or woody material, can promote specific microbial taxa, perhaps as a result of differences in polyphenol to nitrogen ratio (Diedhiou et al. 2009; Baldwin et al. 1983; Kuiters 1990; Hättenschwiler and Vitousek 2000). Numerous studies show that leaf litter input can influence the soil microbial profile, including microbial relative abundance, activity, and function (Diedhiou et al. 2009; Aneja et al. 2006; Mukhopadhyay and Joy 2010). Despite the large number of studies that have examined the relationship between leaf litter and soil microorganisms, little is known about bark litter in this context.

Bark is diverse in chemical composition, and its stem volume varies across species (Harkin and Rowe 1971; Gregoire et al. 1993). The outer bark is external to the vascular cambium and sieves elements that help translocate nutrients from leaves to roots (Rosell 2016; Notaguchi and Okamoto 2015). The targeted role of bark is to protect stems from fire, desiccation, herbivores, and pathogens (Dantas and Pausas 2013; Cernusak and Cheesman 2015; Zas et al. 2011; Pearce 1996; Mullick 1977). Because of a primary role in protection rather than absorption, bark, in contrast to leaves and fine roots, is highly recalcitrant and slow to degrade. However, several forces, including freezethaw events and disturbance from animals, can fragment bark. Bark fragmentation and displacement creates a litter source that is low in nutrient content (Dossa et al. 2016, 2018; Harmon 1989; Shorohova and Kapitsa 2014), but rich in antimicrobial tannins that can impact microbial profiles (Field and Lettinga 1992; Updegraff and Grant 1975). For example, bark contains antimicrobial tannins of a relatively high molecular weight, compared to wood (Feng et al. 2013). As an anti-microbial compound, tannins were reported to lower mycotoxin production and suppress nitrogen mineralization (Peng et al. 2018; Zhang and Laanbroek 2018).

Determining the relationship between bark litter and soil microorganisms will provide further insight into nutrient cycling and brown food-web processes. Soil communities that are regularly exposed to litter deposited from a nearby plant can be thought of as part of the 'home soil' for that plant, which is central to the home-field advantage (HFA) hypothesis (Diepen et al. 2017; Strickland et al. 2009; Ayres et al. 2009b). According to HFA, soil microorganisms that are most efficient at metabolizing litter occur in the 'home soil', as a result of a specialized decomposer-litter relationship (Palozzi and Lindo 2018). The HFA hypothesis has been supported in numerous studies that have examined leaf litter decomposition (Ayres et al. 2009b; Veen et al. 2015; Wang et al. 2013; Perez et al. 2013), but to our knowledge this is the first study to focus on bark in this context. As it pertains to bark decomposition, Shorohova et al. (2012), estimated bark decomposition by observing spruce, pine, and birch stumps; and Wu et al. (2019) examined HFA for intact wood (i.e. branches and bark covered wood). 
To date, many studies have expanded our understanding of ecological factors governing HFA, including edaphic environment, landscape position, global change, and litter traits (Hobbie et al. 2006; Veen et al. 2018; Diepen et al. 2017; Freschet et al. 2012; Fanin et al. 2016). However, most studies that attempt to test the HFA hypothesis hinge on labile litter models, and do not consider recalcitrant litter such as bark. To advance our understanding of this process, this study tests the HFA hypothesis for recalcitrant bark litter. While the definition of home-field advantage (HFA) does not include scale, previous studies suggest that HFA mainly occurs between ecosystems (Ayres et al. 2009a; Wang et al. 2013; Cizungu et al. 2014; Chomel et al. 2015; Sun and Zhao 2016; Asplund et al. 2018). Here we performed a study that tests HFA within an ecosystem, beneath the canopy of two temperate tree species. We address two specific questions: (1) Is the 'home' environment a key factor in determining rates of bark decomposition? (2) Do decomposition of different bark types impact microbial assemblages in the adherent soil? To address these questions, bark from a softwood tree species, eastern hemlock, and a hardwood tree species, white oak, were reciprocally transplanted into 'home' and 'away' environments, in a mixed hardwood forest in central Pennsylvania. We hypothesized that (1) the 'home' environment would increase decomposition rates, and (2) that decomposing bark can initiate change in soil microbial composition.

\section{Methods}

Study system

Mature white oak and eastern hemlock are widespread at the Susquehanna - Shale Hills Critical Zone Observatory $\left(40^{\circ} 39^{\prime} \mathrm{N}, 77^{\circ} 54^{\prime} \mathrm{W}\right)$ in central Pennsylvania. The average temperature in this region is $10^{\circ} \mathrm{C}$ and the mean annual precipitation is $1,006 \mathrm{~mm}$. The underlying soil is derived from shale parent rock residuum (Hasenmueller et al. 2017). The common soil series at this site is Berks-Weikert (Order: Inceptisol, Great Group: Dystrudepts). The percentage of channery shale has been reported to increase with soil depth (White et al. 2015), and the $\mathrm{pH}$ in the top $10 \mathrm{~cm}$ of soil is $\sim 4.0$ (Malik 2019). Bark from eastern hemlock (Tsuga canadensis) and white oak (Quercus alba) were used for this study, as these two species have contrasting life histories and traits. Eastern hemlock is a softwood, late successional, gymnosperm; while white oak is a hardwood, midsuccessional, angiosperm. In addition, these two species face different environmental challenges. Eastern hemlock is on the decline from an invasive sapsucking Hemipteran, known as hemlock wooly adelgid (Mahan et al. 2004), while white oak is on the decline as a result of fire suppression (Abrams 2003). Importantly, these two species deposit distinct types of litter. Eastern hemlock deposits chemically recalcitrant needles, whereas white oak deposits more labile broad leaves. We would expect these differences in litter input to drive differentiation of soil microbial communities, making this an effective system for contrasting 'home' environment effects on bark decomposition.

\section{Experimental design}

This experiment tested for the interactive effect of bark type and soil type on bark decomposition and soil microbial composition. We used a full factorial design featuring two tree species $\times$ two soil types ('home' and 'away') with 25 replicates for each, for a total of 100 observations. Since bark volume is related to stem diameter (Paine et al. 2010), mid-late successional trees were used, so that stem diameter ratios were relatively consistent across individual trees. The 'home' soil for each bark sample was designated as the soil below the canopy of the tree from which it was collected, while the 'away' soil was designated as the soil below the canopy of a randomly selected tree of the other species (Figs. 1b, S1).

\section{Bark excision}

Bark was excised from 50 individual trees, with an excision no deeper between 1.0 and $1.5 \mathrm{~cm}$. The depth of excision, which was consistent across tree individuals, included bark tissue from the dead cell exterior to the outer cambium. The excised bark was then split in half, with one portion designated for burial in the soil community beneath its parent tree ('home' 
(A)
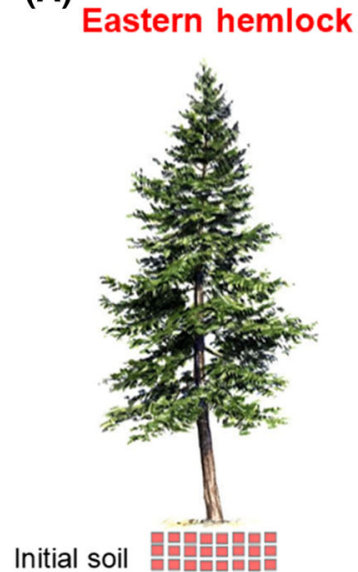

Initial soil $\operatorname{pop}^{+}$

\section{White oak}

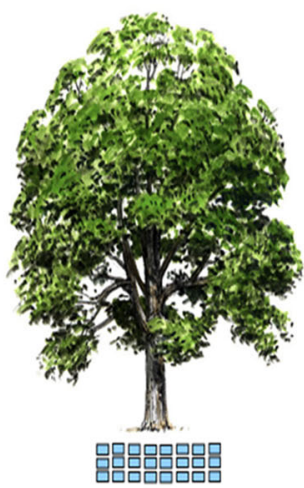

(C)

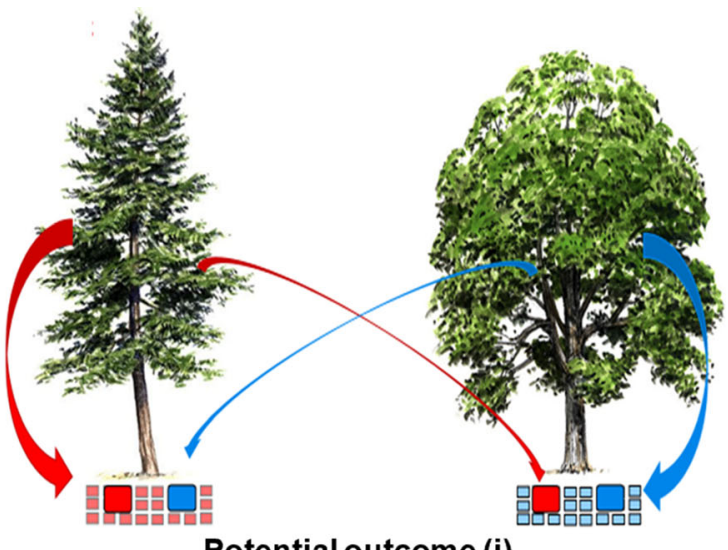

Potential outcome (i)

After 1 year of bark decomposition, soil microbial community does not assemble according to bark identity

(D)

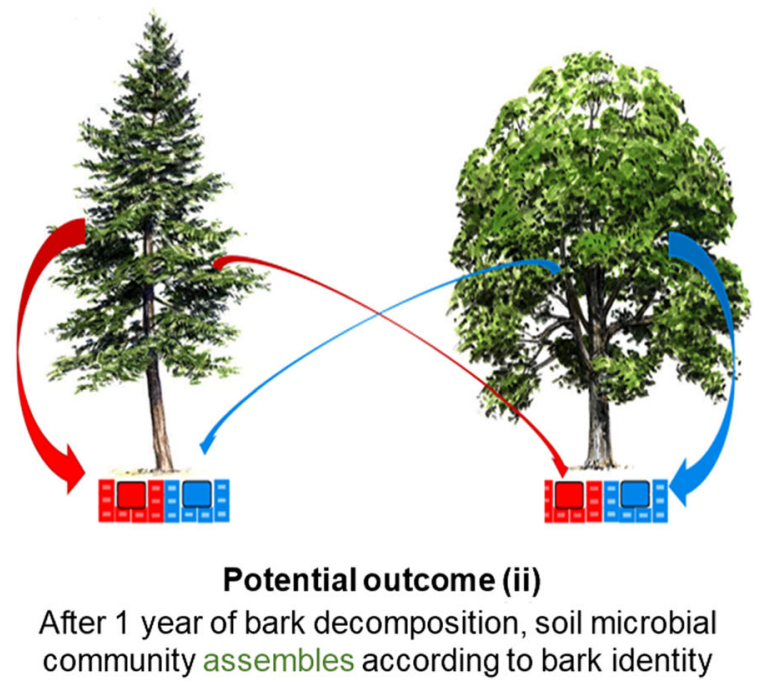

legacy effects, and dominant plants (a). Despite this, bark introduction (b) may or may not have an effect on microbial assemblages (c, d). Note illustration of white oak and eastern hemlock are provided by World Almanac for Kids.com, an imprint of Infobase. Reprinted by permission of the Publisher

$-20{ }^{\circ} \mathrm{C}$ for subsequent analysis of microbial composition. Prior to burial, bark was returned to the lab for initial assessment of bark mass. Bark was oven dried for $20 \mathrm{~h}$ at $40{ }^{\circ} \mathrm{C}$ since water content can vary across tree species (Rosell et al. 2015), and presumably individual samples. 
Field burial and incubation

Dried bark samples were enclosed in cylindrical mesh tubes $(10 \mathrm{~cm}$ long $\times 5 \mathrm{~cm}$ diameter "cores") with $0.5 \mathrm{~cm} \times 0.5 \mathrm{~cm}$ window openings. Two cores were physically paired at each burial site, with one containing bark from the adjacent tree ('home' treatment) and one containing bark from the other tree species (Fig. 1). Paired cores were filled with soil collected at the burial site, and buried horizontally $\sim 37.5 \mathrm{~cm}$ from the trunk of the 'home' tree, similar to Malik (2019). Excavations for core burial were made to $10 \mathrm{~cm}$, since decomposing woody debris frequently occurs at shallow depths (Posada et al. 2012). In addition to bark and decomposing wood being found at this depth, placing bark just few $\mathrm{cm}$ below ground enabled bark to stay at a constant depth across samples, as soil surface placement would have led to stochastic uneven burials. Field incubation occurred from July 2017 to June 2018, after which cores were removed from the field and brought to the laboratory for analysis.

Bark samples were removed from each core and loose soil was shaken off. Directly adherent soil was collected and transferred into 1.5-ml Eppendorf tubes and stored at $-20^{\circ} \mathrm{C}$ before processing for analysis of microbial composition. Bark was then dried for $96 \mathrm{~h}$ at $90{ }^{\circ} \mathrm{C}$. Bark dry mass was then weighed to assess decomposition based on proportionate mass loss.

High-throughput sequencing of bacterial and fungal composition

After a year of decomposition, microbial DNA was assessed in both soil and bark. Initial bark samples were placed in 15-ml sterile water, and agitated overnight at $300 \mathrm{rpm}$. The overnight agitation fragmented the bark which increased the surface area as well as access to internal microbes. The bark fragments were then centrifuged for $30 \mathrm{~min}$ at $21,000 \mathrm{rpm}$. The supernatant was removed and the pellet was used for DNA extraction. Bark fragments were pulverized with ceramic beads during the DNA extraction protocol, thus, enabling microbes living in the bark interior to also be lysed, sampled and extracted. This approach is common to root microbiome sampling (Lundberg et al. 2012). DNA extraction, which included both the bark pellet and the adherent soil colloids, underwent DNA extraction following the manufacturer's recommendations $(\mathrm{Nu}-$ cleoSpin 96 Soil, Macherey-Nagel, Bethlehem, PA, USA).

To examine the bacterial and fungal composition of the bark and adherent soil, a two-step amplification approach was used to produce Illumina-compatible amplicons. The bacterial primers 515F (5'-GTGYCAGCMGCCGCGGTAA-3') and 806R (5'-GGACTACNVGGGTWTCTAAT- $3^{\prime}$ ) were used to target the v4 region of the 16S rRNA gene (Apprill et al. 2015; Parada et al. 2016), and the fungal primers ITS1F (5'CTTGGTCATTTAGAGGAAGTAA-3') and 58A2R (5'-CTGCGTTCTTCATCGAT-3') were used to target the ITS1 region of the ribosomal RNA gene (Gardes and Bruns 1993; Martin and Rygiewicz 2005). Primers were designed with overhangs that allow the attachment of barcodes and standard Illumina overhang adaptors in a second PCR step.

Initial PCR was performed in mixtures of: $8 \mu \mathrm{l}$ of 5Prime HotStart MasterMix (Quanta BioSciences Inc., Beverly, MA, USA), $0.2-4 \mu \mathrm{l}$ of template DNA, $1 \mu \mathrm{l}$ of each primer from $10 \mu \mathrm{M}$ stocks, and the appropriate volume of molecular biology grade water to bring the reaction to $20 \mu \mathrm{l}$. The following protocol was performed for $16 \mathrm{~S}$ rRNA gene amplicons: $94{ }^{\circ} \mathrm{C}$ for $3 \mathrm{~min} ; 25$ cycles of $94^{\circ} \mathrm{C}$ for $30 \mathrm{~s}, 55$ ${ }^{\circ} \mathrm{C}$ for $30 \mathrm{~s}$, and $72{ }^{\circ} \mathrm{C}$ for $45 \mathrm{~s}$; and then a final elongation for $10 \mathrm{~min}$ at $72{ }^{\circ} \mathrm{C}$. Separately, ITS amplicons were produced using the following protocol: $94{ }^{\circ} \mathrm{C}$ for $3 \mathrm{~min} ; 35$ cycles of $94{ }^{\circ} \mathrm{C}$ for $20 \mathrm{~s}, 45^{\circ} \mathrm{C}$ for $30 \mathrm{~s}$, and $72{ }^{\circ} \mathrm{C}$ for $45 \mathrm{~s}$; and then a final elongation for $5 \mathrm{~min}$ at $72{ }^{\circ} \mathrm{C}$. Post-PCR, amplicons were purified using Mag-Bind TotalPure NGS (Omega Bio-Tek, Norcross, GA, USA) magnetic beads. Next, standard Illumina overhang adaptors and unique indexing barcodes were added to both 16S and ITS amplicons from each sample during a second PCR step where $5 \mu \mathrm{l}$ of cleaned PCR product, $12.5 \mu \mathrm{l}$ of 5Prime Hotstart Mastermix, $2.5 \mu \mathrm{l}$ of water, and $2.5 \mu \mathrm{l}$ of index primer $(10 \mu \mathrm{M})$ were added to the reactions and amplified under the following conditions: $98{ }^{\circ} \mathrm{C}$ for $1 \mathrm{~min} ; 8$ cycles of $98^{\circ} \mathrm{C}$ for $15 \mathrm{~s}, 55^{\circ} \mathrm{C}$ for $30 \mathrm{~s}$, and $72{ }^{\circ} \mathrm{C}$ for $20 \mathrm{~s}$, followed by a final elongation for $5 \mathrm{~min}$ at $72{ }^{\circ} \mathrm{C}$. All amplifications were made using Mastercycler Nexus Gradient PCR machines (Eppendorf, Hamburg, Germany). Amplicon yields were normalized using the SequalPrep Normalization Plate Kit (Invitrogen, Carlsbad, CA, USA) and pooled. The pool was concentrated using a Savant SpeedVac (Thermo 
Scientific, Waltham, MA, USA) for $3 \mathrm{~h}$ at $50{ }^{\circ} \mathrm{C}$ and subsequently run on an agarose gel $(1.2 \%)$. The band of expected size was then excised and purified using the PureLink Quick Gel Extraction kit (Invitrogen, Carlsbad, CA, USA).

Sequencing was performed at the Cornell University Biotechnology Resource Center Genomics Facility on an Illumina MiSeq $(2 \times 250$ cycle, v2 kit $)$. Bacterial 16S rRNA gene sequencing yielded a total of $4,541,319$ contigs following merging of forward and reverse reads across 90 libraries. After quality filtering, 631,548 total reads were obtained across 90 samples. This provided an average of 7017 reads/ sample. Fungal ITS sequencing yielded a total of $5,386,484$ contigs after merging forward and reverse reads across 90 libraries. After quality filtering, we obtained 2,302,039 total reads across 90 samples, providing an average of 25,578 reads/sample. Raw sequence reads were submitted the NCBI SRA under the accession PRJNA587721.

\section{Bioinformatic and data assessment}

Read processing was performed mostly as described by Howard et al. (2017), based on a modified Brazilian Microbiome Project pipeline for both the 16S and ITS datasets (Pylro et al. 2014). Briefly, forward and reverse reads were merged (make.contigs) and primer sequences trimmed (trim.seqs, pdiffs $=2$, maxambig $=0$ ) in Mothur v1.39.5 (Schloss et al. 2009) as singletons were removed. Reads were then split by sample into individual files for downstream processing in MacQIIME v1.9.1 (Caporaso et al. 2010). Qiimecompatible labels were added to the sequences which were then dereplicated (-derep_fulllength) with VSEARCH v2.3.4 (Rognes et al. 2016), 97\% OTUs picked (-cluster_otus) with USEARCH v7 (Edgar 2010). Chimeric reads were removed (-uchime_ref) in USEARCHv7 using the rdp_gold database. OTUs were then assigned taxonomy (classify.seqs) in Mothur v1.39.5 using the May 2013 greengenes release for 16S rRNA gene OTUs and the UNITEv7 database for fungal ITS OTUs. For the 16S rRNA gene dataset, OTUs classified as 'Archaea', 'Eukaryota', 'chloroplast', 'mitochondria', and 'unknown' were excluded from the dataset. OTUs classified as 'Plantae', 'Protista', 'Animalia', 'Protozoa', and 'unknown' were removed from the ITS dataset. The resulting OTU and taxonomy tables were analyzed using R v3.4.4.

Decomposition analysis and statistics

Samples were rarefied to obtain an even number of sequences per sample. The vegan v2.4.4 package (Oksanen et al. 2013) was used to calculate diversity indices and Bray-Curtis dissimilarities and perform principal-coordinates analyses (PCoA). The effect of initial bark and soil treatments on microbial community composition was assessed with global PERMANOVA tests (Anderson 2001) for both bacterial and fungal composition using the 'adonis' function in vegan. Group dispersion was then assessed using the 'betadisper' function in vegan and differences in distances to group centroids were tested using ANOVA. Here, group was set as the explanatory variable and distance to group centroid was set as the response variable. Tukey HSD was employed for posthoc analysis.

Relative decomposition was evaluated as proportionate change in mass ( $\Delta$ mass/initial mass). Proportionate change in mass was used to test for HFA. Bark tissue decomposed beneath the canopy of the tree in which it originated (home), while a portion of the tissue decomposed beneath the canopy of a different species ('away'). The difference in bark decomposition rate at 'home' versus 'away' was used to calculate the HFA index (Ayres et al. 2009b).

The effect of soil environment on decomposition was determined using analysis of variance (ANOVA). ANOVA was justified by assessing normality visually via kernel density plots in $R$ version 3.3 .3 and Levene's test was employed to assess homogeneity of variance. For ANOVA, tree species (oak and hemlock) and soil environment ('home' and 'away') were set as explanatory variables, with decomposition set as the response variable. The explanatory variable consisted of four levels, hemlock bark in hemlock soil; hemlock bark in white oak soil; white oak bark in white oak soil; and white oak bark in hemlock soil (Fig. S1). Tukey's HSD was used for post-hoc analysis.

Our analysis was performed in two ways. First, the ANOVA model was decomposed into apriori contrasts using the multcomp package (Hothorn et al. 2013) followed by simultaneous tests of general linear hypotheses (Hothorn et al. 2008). While not directly related to the main goals of this study, contrasts also 
included the means of 'eastern hemlock soil environment' versus 'white oak soil environment'; means of 'eastern hemlock bark substrate' versus 'white oak bark substrate'. A two-way ANOVA was also performed, since it is a common statistical approach for this type of experimental design. A two-way ANOVA can reveal an interaction, such that the outcome of one factor (i.e. bark type) is dependent on the levels of another factor (i.e. soil type). To assess HFA, a onesample t-test was performed on each species to determine whether HFA analysis was significant (i.e different from zero).

\section{Hypothesis testing}

As with leaf litter, we expected bark would decompose faster within soils near the tree from which it was collected, demonstrating a home-field advantage. If the first hypothesis is true, bark should decompose faster when it is in its "home" soil community, resulting in an HFA index above zero (Fig. 1). We also expect that different bark types will differentially shift microbial assemblages. If the second hypothesis is true, microbial assemblages, will sort according to the identity of the introduced bark, as opposed to the soil regime (Fig. 1).

For the two-way ANOVA, we would interpret a significant interaction between bark type and soil type to mean that bark decomposition is uniquely dependent on the combination of soil type and bark type, which may suggest HFA. A nonsignificant interaction may suggest that decomposition rate is influenced by species bark type, soil type, or both.

\section{Results}

\section{Bark HFA}

The calculated HFA index indicated a clear "homefield advantage" to decomposition for white oak bark (Fig. 2, white oak, $t=5.1446, \mathrm{~d} f=24,95 \%$ CI $[0.05,0.13], p=2.883 \mathrm{e}-05)$ and a home-field disadvantage for eastern hemlock bark (Fig. 2, eastern Hemlock, $t=-2.928, d f=23,95 \% \mathrm{CI}_{[-0.16,-0.02]}$, $p=0.007)$, meaning that bark decomposition was consistently faster in white oak soils. In addition, our soil treatments were significant predictors of bark decomposition (Fig. 3, ANOVA, $F_{3,96}=5.15$, $p=0.002$ ). Hence, when mean bark decomposition in white oak soils was compared to that in eastern hemlock soils, decomposition was greater in white oak soils (ANOVA, Simultaneous Tests for GLH, 95\% CI $[-0.33,-0.03], p=0.01)$. Bark type was also a factor in decomposition rates; irrespective of soil type, eastern hemlock bark decomposed faster than white oak bark (S2, ANOVA, a priori contrasts, Simultaneous Tests for $\left.\mathrm{GLH}, 95 \% \mathrm{CI}_{[-0.30,0.00]}, p=0.05\right)$. A two-way ANOVA showed that both bark source $\left(F_{1,96}=6.151\right.$, $p=0.01487)$ and soil type $\left(F_{1,96}=9.316\right.$, $p=0.00294)$ were both significant predictors of decomposition, but this test did not detect an interaction between these two factors $\left(F_{1,96}=0.011\right.$, $p=0.91614)$. This indicates decomposition rate is mainly influenced by bark type and soil type, while evidence for HFA is unclear.

Bark and soil specific clustering of microbial communities

Bark decomposition impacted microbial composition in nearby soil. A PCoA ordination of $16 \mathrm{~S}$ rRNA gene OTUs based on Bray-Curtis distances showed that bark type influences bacterial and fungal composition, and these differences persisted in the bark-adherent soil, irrespective of soil type (Fig. 4a, PERMANOVA, $\left.F_{5,74}=16.01, p<0.001\right)$. Similar patterns were observed for fungi (Fig. 4b, PERMANOVA, $\left.F_{5,78}=5.58, p<0.001\right)$. Beta-dispersion analysis demonstrated that only white oak bark in the $16 \mathrm{~S}$ dataset and hemlock bark in the ITS dataset differed in group dispersion compared to other treatment types (Supplemental Fig. S3; 16S: ANOVA $\mathrm{F}_{5-74}=8.52$, $\mathrm{p}=2.07 \mathrm{e}-6 ; \quad$ ITS: $\quad$ ANOVA, $\quad \mathrm{F}_{5-78}=10.72$, $\mathrm{p}=7.31 \mathrm{e}-8)$.

\section{Discussion}

In the context of this study, decomposition proceeded more rapidly in white oak soils than in eastern hemlock soils, while hemlock bark decomposed more rapidly than white oak bark overall. With respect to decomposition, the home-field advantage (HFA) hypothesis suggests that in particular points in space, the accumulation of specific litter types will shape the composition and activity of soil communities to promote those that are most efficient at metabolizing 


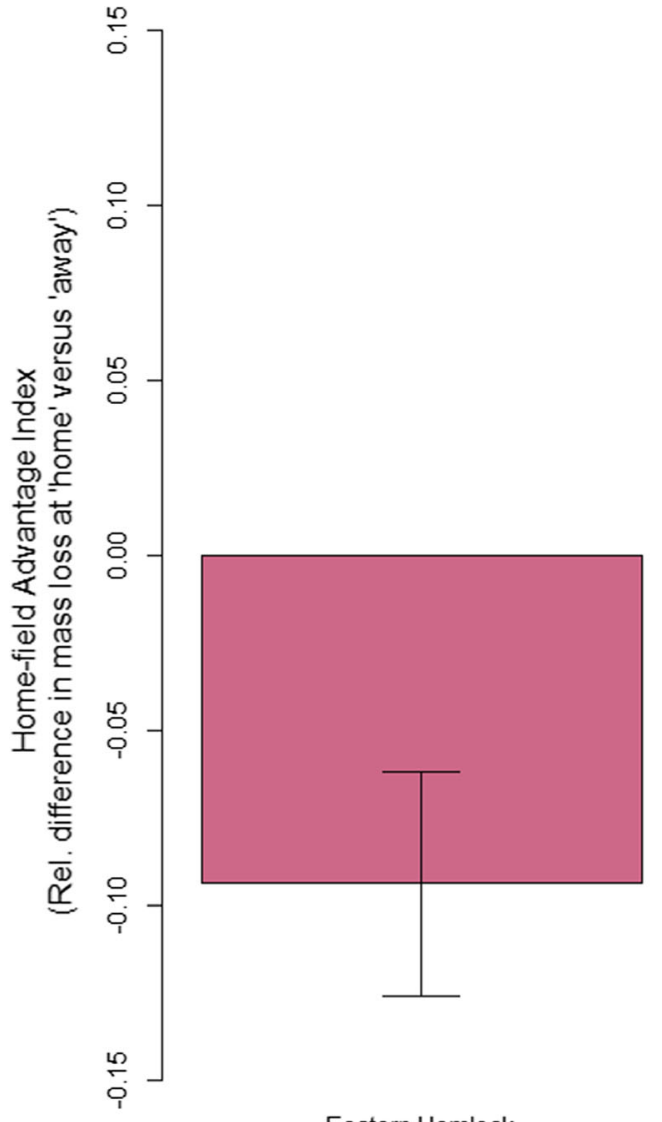

Eastern Hemlock

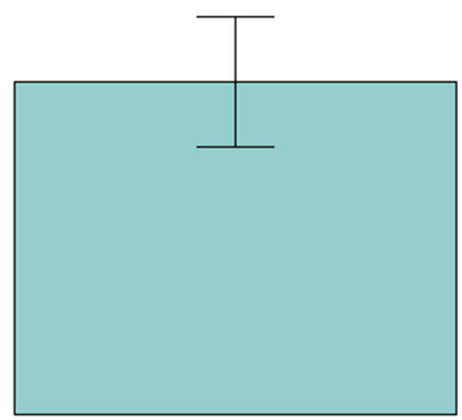

White oak

\section{Bark tissue}

Fig. 2 Home Field Advantage (HFA) Index. To test if bark preferentially decomposed near to the tree from which it was collected, decomposition of eastern hemlock and white oak bark was observed in 'home' and 'away' soils. The difference in 'home' and 'away' decomposition rates is used to formulate the

the available resources. Other hypotheses, including substrate quality, functional breadth, rhizosphere priming, and Gadgil effect, provide alternative views of the controls on decomposition pathways (Chapman et al. 2003; Hättenschwiler et al. 2011; Sinsabaugh and Shah 2011; Freschet et al. 2012; Sulman et al. 2017; Malik 2019; Fanin et al. 2016). Here we aimed to determine whether HFA could be detected for bark. Although the HFA index suggested preferential decomposition for white oak bark in "home" soils, it was clear that white oak soils also promoted the decomposition of hemlock bark, and we did not observe a significant bark type $\mathrm{x}$ soil type interaction based on a two-way ANOVA. Bark type also had a strong influence on the composition of adjacent soil
HFA index. Positive values indicate greater mass loss at home. A significant HFA was detected for white oak (One sample t-test, $p=2.883 \mathrm{e}-05$ ), while a significant home-field disadvantage was detected for eastern hemlock (One sample t-test, $p=0.007$ )

microorganisms, regardless of soil type. Taken together, these findings suggest that the solubilization of bark and/or the introduction of bark-borne microorganisms may influence short-term local succession in microbial assemblages, but without lasting impacts, these trends are less likely to influence the suitability of recalcitrant litter decomposability.

\section{Plant traits can affect bark decomposition}

In this study, we used two trees with contrasting traits: softwood, coniferous eastern hemlock, versus hardwood deciduous, white oak. The deposition of litter with varied traits can influence soil microbial abundance, colonization, and enzymatic activity in 


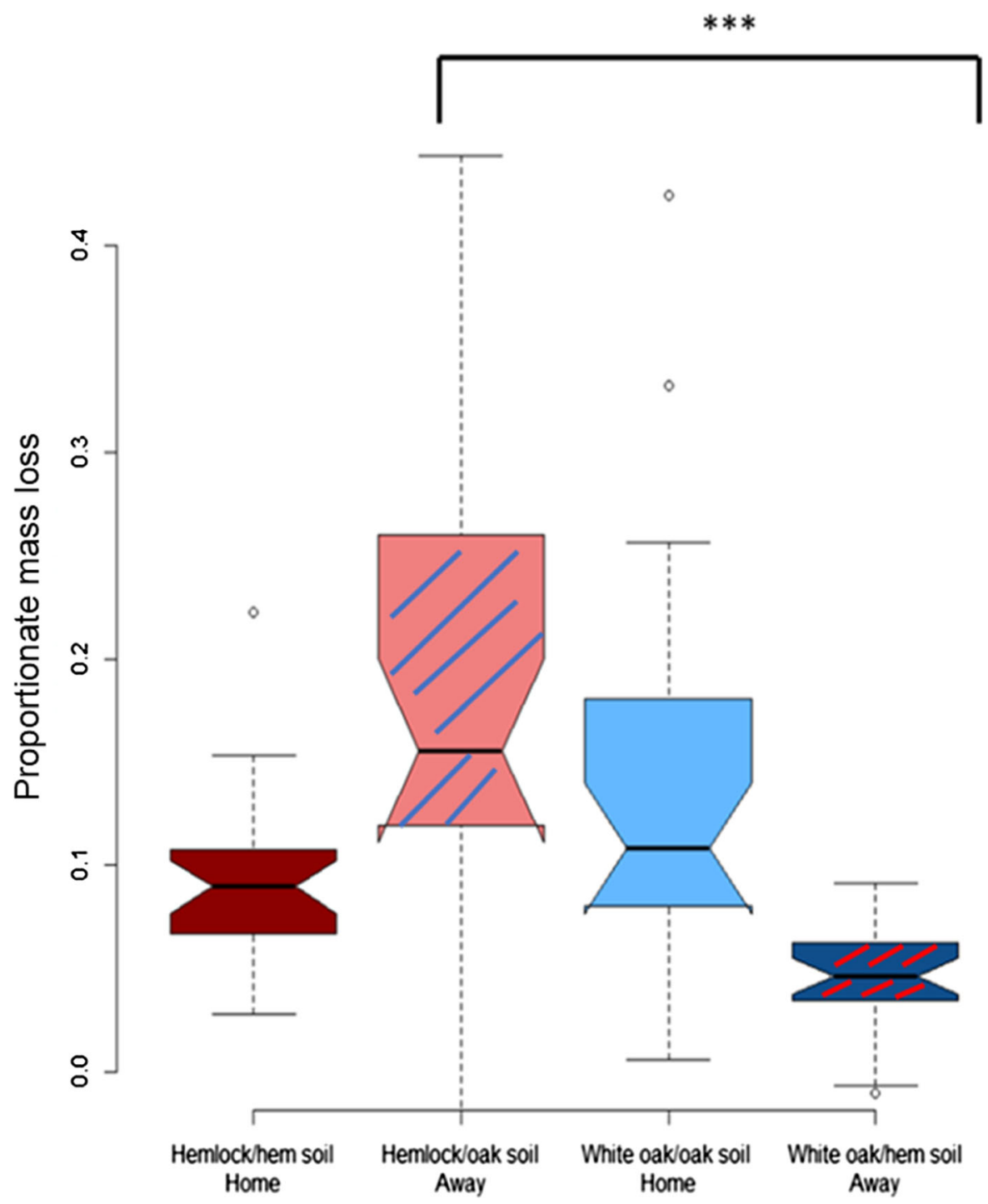

Fig. 3 Bark decomposition in soil communities. Depicted here are boxplots showing the effect of each treatment. Hashmarks within a boxplot represent bark in away soils. The notches in each boxplot represents $95 \% \mathrm{CI}$ around the mean. The upper edge and lower edge of each boxplot is the $25 \%$ and $75 \%$ quartile, that make up the interquartile. The whiskers represent $1.5 \times$ the interquartile. Points beyond the whiskers are outliers. Analysis of variance (ANOVA) suggest that these treatments

different ways, depending on the traits of the plants producing litter, which can be shaped by how particular plants interact with the environment (Diedhiou et al. 2009; Aneja et al. 2006; Mukhopadhyay and Joy 2010). For example, plant populations responding to stress from insect pests (e.g. eastern hemlock) have been shown to increase production in polyphenolics significantly impacted bark decomposition $\left(F_{3}, 96=5.15\right.$, $p=0.002)$. Also, decomposition appeared to be lower in eastern hemlock soils. These differences were significant when contrasted (ANOVA, apriori contrast, white oak soils versus eastern hemlock soils 95\% CI $[-0.33,-0.03], p=0.01)$. There were also significant differences in decomposition when comparing the two away treatments (Tukey HSD, $p<0.001$ )

(Constabel and Ryan 1998; Bhonwong et al. 2009; Dar et al. 2017), which can impact decomposition. Meanwhile adaptations to frequent fire disturbance (e.g. white oak) may result in thicker outer bark (Rosell 2016), which could reduce wood access to decomposers, and decrease the rate of carbon cycling. Our results suggest that bark decomposition was slower in 


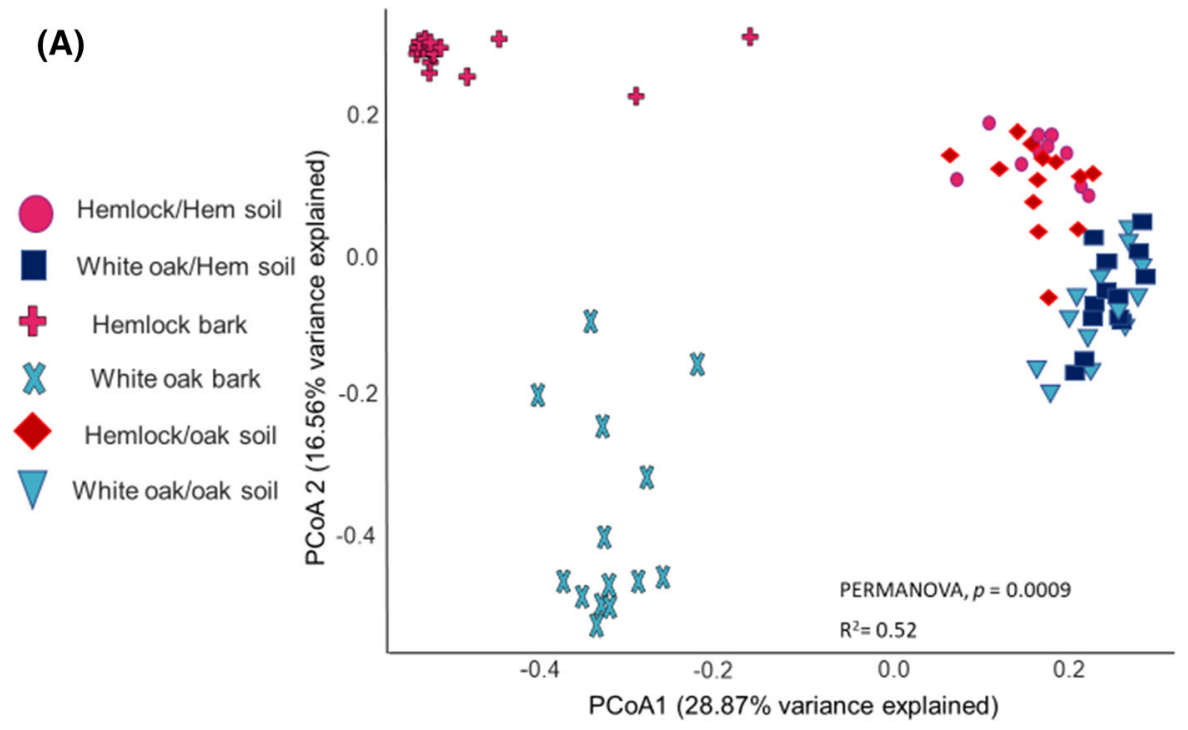

(B)

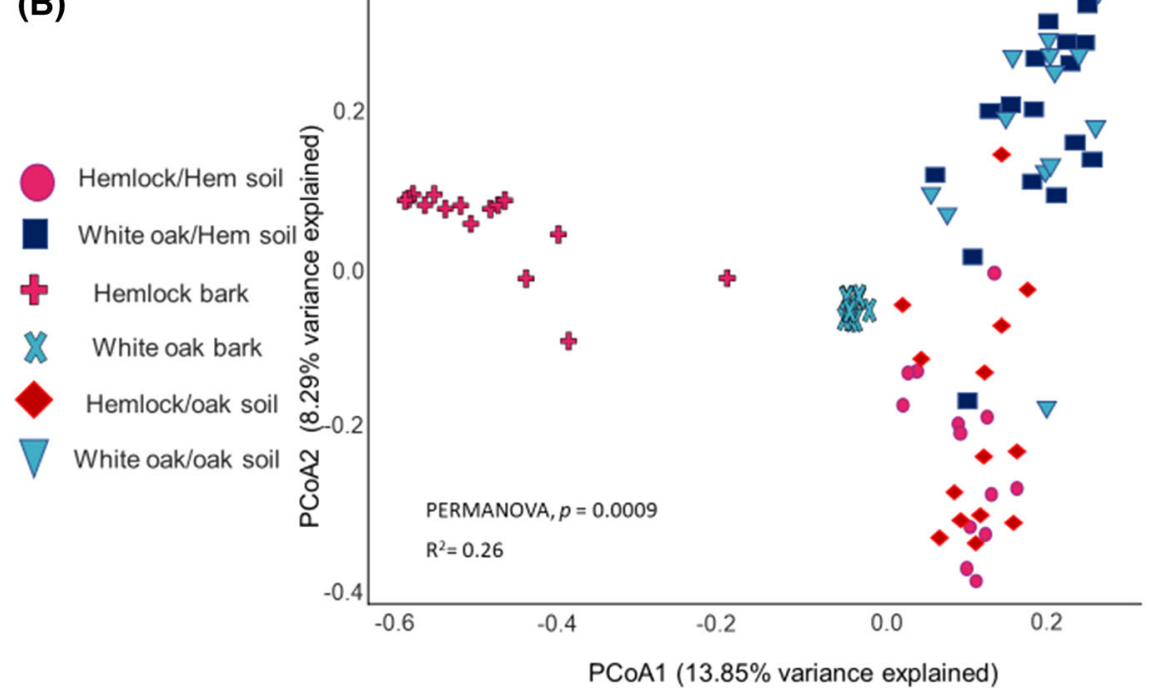

Fig. 4 Similarities and dissimilarities of microbial communities across treatments. a Bacteria: depicted here are community similarities and dissimilarities among bacterial assemblages in the vicinity of decomposing bark (PERMANOVA,

soils beneath the canopy of eastern hemlock than those of white oak (Fig. 3), essentially creating a HFA for white oak and not eastern hemlock (Fig. 2); however, whether this effect is due to characteristics that are inherent to soils in which these trees grow or to soil conditioning by white oaks cannot be determined here. Bark traits are also likely to have influenced rates of decomposition both directly (hemlock decomposed more quickly than white oak; Figure S2) and through
$\left.\mathrm{F}_{5,74}=16.01, p<0.001\right)$. b Fungi: depicted here are similarities and dissimilarities among fungal assemblages in the vicinity of decomposing bark (PERMANOVA, $\mathrm{F}_{5}, 78=5.58$, $p<0.001)$

modification of soil microbial composition (Fig. 4a, b).

Environmental factors in decomposition

Various soil traits can impact decomposition. Decomposition was consistently slower in eastern hemlock soils than that of white oak soils, suggesting a systematic difference between the tree-adjacent soils. 
Soil traits that covary with the preferred habitats of each tree species could overwhelm any potential HFA for bark decomposition. For instance, fine roots that play a role in nutrient, carbon and water cycling; can also impact decomposition (Cheng and Kuzyakov 2005; McCormack et al. 2015), while topographic control of soil moisture distribution (e.g. subsurface flow; slope position) can alter substrate decomposability (Burt and Butcher 1985; Nippgen et al. 2011). Differences in canopy cover can also impact soil moisture content (Duff et al. 1997). It is also possible that the legacy of eastern hemlock needles influenced soil $\mathrm{pH}$, which may have impacted invertebrate activity (Beyer et al. 1987), and rates of decomposition (Ayanaba and Jenkinson 1990).

White oak soils and the functional breadth hypothesis

While this study was designed to test for HFA, there are competing hypotheses, including the functional breadth hypothesis (Keiser et al. 2014), which may provide an alternative explanation. Overall, bark decomposed more readily in white oak soils (Fig. 3), which could indicate that white oak soils have a broader range of functions related to decomposition than hemlock soils. A broader functional breadth of microbial activity is achieved when there is broad spectrum of labile and recalcitrant litter. This may explain why forests are expected to have a broader functional breadth than either grasslands or agroecosystems (Fanin et al. 2016). As it relates to litter deposition with a greater range along the labilerecalcitrant spectrum, hardwood soils may exhibit a greater range than hemlock soil due to dissimilarity in microbial machinery required to degrade the hemicellulose backbone. This explanation is partly based on the higher xylan and lower mannan content of hardwood hemicellulose than that of softwoods (Zhu and Pan 2010). Thus, the main hemicellulases involved in the degradation of hardwood hemicellulose are xylanases, beta-xylosidases and xyloglucanases (Álvarez et al. 2016). In contrast, mannanases and beta-mannosidases are preferentially used to degrade the hemicellulose backbone of softwoods (Álvarez et al. 2016). This contrast in enzymatic machinery suggests different modes of decomposition, which likely leads to differences in microbial assemblages and function, which is relevant to this study. At the labile end of the labile-recalcitrant spectrum, hardwoods may also broaden soil community function due to the frequency of broad leaf deposition that is often of higher $\mathrm{N}$ content and less acid-forming than hemlock leaf litter (Yates et al. submitted).

Decomposition and litter traits may shape community structure

Bark decomposition may impact local soil environments, at least in the short term. Variation in local microbial composition was explained more by bark type than soil environment (Fig. 4a, b). One explanation is that bark brings a resident microbiome to soil, which may persist through time. Alternatively, soil microbial composition may have been impacted during decomposition by the liberation of bark specific compounds. Dossa et al. (2018) showed that bark decomposition can influence soil faunal assemblages, indicating that environmental changes can be mediated at the local scale by recalcitrant litter at multiple trophic levels. As decomposition progresses, there is a change in a substrate's rigidity, density and mass (Pyle and Brown 1998), which can reflect nitrogen mineralization and lignocellulose solubilization (Melillo et al. 1982; Pointing et al. 2003). Progressive change in bark decomposition was shown to impact soil microbial composition, which may in turn provide insight into nutrient cycling and carbon storage.

\section{Conclusion}

Common history among microbes and fallen litter is foundational to the "home-field advantage" hypothesis (Strickland et al. 2009; Ayres et al. 2009b). Mixed results were observed in this decomposition study. Although we observed higher decomposition of white oak bark in 'home' environments, decomposition of hemlock bark was also higher in white oak soils. This type of soil effect could be due either to environmental conditioning by white oaks, or by differences that are inherent to the locations that white oak and hemlock preferentially grow within a forest. Bark type rather than soil environment, was a significant predictor of microbial composition in the adherent soil community. Here we show that the decomposition of recalcitrant litter can influence microbial composition in 
the short-term, possibly due to an influx of bark-borne microorganisms or the liberation of polyphenolics, anti-microbial tannins and other chemical compounds, but that this may not necessarily lead to sustained advantages in decomposition for 'home' bark.

Acknowledgements College of Agricultural Sciences and Huck Institutes of Life Sciences - Ecology Program. Special thanks to Mary Ann Bruns, Armen Kemanian, Jason Kaye, Alan H. Taylor and David Munoz for helpful discussions. This work was supported by the USDA National Institute of Food and Hatch Appropriations under Project \#PEN04651 and Accession \#1016233 and \#PEN04591, Accession \#1006803. The field work was conducted in Penn State's Stone Valley Forest, which is supported and managed by the Penn State's Forestland Management Office in the College of Agricultural Sciences and facilitated by National Science Foundation Critical Zone Observatory program grants to C. Duffy (EAR 07-25019) and S. Brantley (EAR 12-39285, EAR 13-31726). Financial support was also provided by Penn State's Button Waller Fellowship, and National Science Foundation PRFB Award \#1907242. Special thanks to Laurie E. Likoff of infobase learning for granting permission to re-use illustrations of eastern hemlock and white oak. Also, thank you to reviewer 1 for helping improve this manuscript by suggesting addition statistical approaches for hypothesis testing.

Open Access This article is licensed under a Creative Commons Attribution 4.0 International License, which permits use, sharing, adaptation, distribution and reproduction in any medium or format, as long as you give appropriate credit to the original author(s) and the source, provide a link to the Creative Commons licence, and indicate if changes were made. The images or other third party material in this article are included in the article's Creative Commons licence, unless indicated otherwise in a credit line to the material. If material is not included in the article's Creative Commons licence and your intended use is not permitted by statutory regulation or exceeds the permitted use, you will need to obtain permission directly from the copyright holder. To view a copy of this licence, visit http://creativecommons.org/licenses/by/4.0/.

\section{References}

Abrams MD (2003) Where has all the white oak gone? Bioscience 53:927-939

Álvarez C, Reyes-Sosa FM, Díez B (2016) Enzymatic hydrolysis of biomass from wood. Microb Biotechnol 9:149-156

Anderson MJ (2001) A new method for non-parametric multivariate analysis of variance. Austral Ecol 26:32-46

Aneja MK, Sharma S, Fleischmann F, Stich S, Heller W, Bahnweg G, Munch JC, Schloter M (2006) Microbial colonization of beech and spruce litter-influence of decomposition site and plant litter species on the diversity of microbial community. Microb Ecol 52:127-135
Apprill A, Mcnally S, Parsons R, Weber L (2015) Minor revision to V4 region SSU rRNA 806R gene primer greatly increases detection of SAR11 bacterioplankton. Aquat Microb Ecol 75:129-137

Asplund J, Kauserud H, Bokhorst S, Lie MH, Ohlson M, Nybakken L (2018) Fungal communities influence decomposition rates of plant litter from two dominant tree species. Fungal Ecol 32:1-8

Ayanaba A, Jenkinson D (1990) Decomposition of carbon-14 labeled ryegrass and maize under tropical conditions. Soil Sci Soc Am J 54:112-115

Ayres E, Steltzer H, Berg S, Wall DH (2009a) Soil biota accelerate decomposition in high-elevation forests by specializing in the breakdown of litter produced by the plant species above them. J Ecol 97:901-912

Ayres E, Steltzer H, Simmons BL, Simpson RT, Steinweg JM, Wallenstein MD, Mellor N, Parton WJ, Moore JC, Wall DH (2009b) Home-field advantage accelerates leaf litter decomposition in forests. Soil Biol Biochem 41:606-610

Baldwin IT, Olson RK, Reiners WA (1983) Protein binding phenolics and the inhibition of nitrification in subalpine balsam fir soils. Soil Biol Biochem 15:419-423

Bardgett R (2016) Earth matters: how soil underlies civilization. Oxford University Press, Oxford

Beyer W, Hensler G, Moore J (1987) Relation of $\mathrm{pH}$ and other soil variables to concentrations of $\mathrm{Pb}, \mathrm{Cu}, \mathrm{Zn}, \mathrm{Cd}$, and $\mathrm{Se}$ in earthworms. Pedobiologia 30:167-172

Bhonwong A, Stout MJ, Attajarusit J, Tantasawat P (2009) Defensive role of tomato polyphenol oxidases against cotton bollworm (Helicoverpa armigera) and beet armyworm (Spodoptera exigua). J Chem Ecol 35:28-38

Burt T, Butcher D (1985) Topographic controls of soil moisture distributions. J Soil Sci 36:469-486

Caporaso JG, Kuczynski J, Stombaugh J, Bittinger K, Bushman FD, Costello EK, Fierer N, Pena AG, Goodrich JK, Gordon JI (2010) QIIME allows analysis of high-throughput community sequencing data. Nat Methods 7:335

Cebrian J (1999) Patterns in the fate of production in plant communities. Am Nat 154:449-468

Cernusak LA, Cheesman AW (2015) The benefits of recycling: how photosynthetic bark can increase drought tolerance. New Phytol 208:995-997

Chapman SK, Hart SC, Cobb NS, Whitham TG, Koch GW (2003) Insect herbivory increases litter quality and decomposition: an extension of the acceleration hypothesis. Ecology 84:2867-2876

Chapman SK, Newman GS, Hart SC, Schweitzer JA, Koch GW (2013) Leaf litter mixtures alter microbial community development: mechanisms for non-additive effects in litter decomposition. PLoS ONE 8:e62671

Cheng W, Kuzyakov Y (2005) Root effects on soil organic matter decomposition. Roots and soil management: interactions between roots and the soil. ASA-CSSA-SSSA, Madison, pp 119-143

Chomel M, Guittonny-Larchevêque M, Desrochers A, Baldy V (2015) Home field advantage of litter decomposition in pure and mixed plantations under boreal climate. Ecosystems 18:1014-1028

Cizungu L, Staelens J, Huygens D, Walangululu J, Muhindo D, Van Cleemput O, Boeckx P (2014) Litterfall and leaf litter 
decomposition in a central African tropical mountain forest and Eucalyptus plantation. For Ecol Manag 326:109-116

Constabel CP, Ryan CA (1998) A survey of wound-and methyl jasmonate-induced leaf polyphenol oxidase in crop plants. Phytochemistry 47:507-511

d'Annunzio R, Zeller B, Nicolas M, Dhôte J-F, Saint-ANDRÉ L (2008) Decomposition of European beech (Fagus sylvatica) litter: combining quality theory and $15 \mathrm{~N}$ labelling experiments. Soil Biol Biochem 40:322-333

Dantas VDL, Pausas JG (2013) The lanky and the corky: fireescape strategies in savanna woody species. J Ecol 101:1265-1272

Dar A, Rather B, Wani A, Ganie M (2017) Resistance against insect pests by plant phenolics and their derivative compounds. Chem Sci Rev Lett 6:1073-1081

Diedhiou S, Dossa E, Badiane A, Diedhiou I, Sene M, Dick R (2009) Decomposition and spatial microbial heterogeneity associated with native shrubs in soils of agroecosystems in semi-arid Senegal. Pedobiologia 52:273-286

Diepen LTA, Frey SD, Landis EA, Morrison EW, Pringle A (2017) Fungi exposed to chronic nitrogen enrichment are less able to decay leaf litter. Ecology 98:5-11

Dossa GG, Paudel E, Cao K, Schaefer D, Harrison RD (2016) Factors controlling bark decomposition and its role in wood decomposition in five tropical tree species. Sci Rep $6: 34153$

Dossa GG, Schaefer D, Zhang JL, Tao JP, Cao KF, Corlett RT, Cunningham AB, Xu JC, Cornelissen JH, Harrison RD (2018) The cover uncovered: bark control over wood decomposition. J Ecol 106:2147-2160

Duff G, Myers B, Williams R, Eamus D, O'Grady A, Fordyce I (1997) Seasonal patterns in soil moisture, vapour pressure deficit, tree canopy cover and pre-dawn water potential in a northern Australian savanna. Aust J Bot 45:211-224

Edgar RC (2010) Search and clustering orders of magnitude faster than BLAST. Bioinformatics 26:2460-2461

Fanin N, Fromin N, Bertrand I (2016) Functional breadth and home-field advantage generate functional differences among soil microbial decomposers. Ecology 97:1023-1037

Feng S, Cheng S, Yuan Z, Leitch M, Xu CC (2013) Valorization of bark for chemicals and materials: a review. Renew Sustain Energy Rev 26:560-578

Field J, Lettinga G (1992) Toxicity of tannic compounds to microorganisms. In: Plant polyphenols. Springer, Boston

Freschet GT, Aerts R, Cornelissen JH (2012) Multiple mechanisms for trait effects on litter decomposition: moving beyond home-field advantage with a new hypothesis. J Ecol 100:619-630

Gardes M, Bruns TD (1993) ITS primers with enhanced specificity for basidiomycetes-application to the identification of mycorrhizae and rusts. Mol Ecol 2:113-118

Gessner MO, Swan CM, Dang CK, McKie BG, Bardgett RD, Wall DH, Hättenschwiler S (2010) Diversity meets decomposition. Trends Ecol Evol 25:372-380

Glassman SI, Weihe C, Li J, Albright MB, Looby CI, Martiny AC, Treseder KK, Allison SD, Martiny JB (2018) Decomposition responses to climate depend on microbial community composition. Proc Natl Acad Sci USA 115:11994-11999
Gregoire T, Valentine H, Furnival G (1993) Estimation of bole surface area and bark volume with Monte Carlo methods. Biometrics 49:653-660

Harkin JM, Rowe JW (1971) Bark and its possible uses. (Research note FPL; 091): 56 p, 91

Harmon ME (1989) Effects of bark fragmentation on plant succession on conifer logs in the Picea-Tsuga forests of Olympic National Park, Washington. Am Midland Nat 121:112-124

Hasenmueller EA, Gu X, Weitzman JN, Adams TS, Stinchcomb GE, Eissenstat DM, Drohan PJ, Brantley SL, Kaye JP (2017) Weathering of rock to regolith: the activity of deep roots in bedrock fractures. Geoderma 300:11-31

Hättenschwiler S, Vitousek PM (2000) The role of polyphenols in terrestrial ecosystem nutrient cycling. Trends Ecol Evol 15:238-243

Hättenschwiler S, Coq S, Barantal S, Handa IT (2011) Leaf traits and decomposition in tropical rainforests: revisiting some commonly held views and towards a new hypothesis. New Phytol 189:950-965

Hobbie SE, Reich PB, Oleksyn J, Ogdahl M, Zytkowiak R, Hale C, Karolewski P (2006) Tree species effects on decomposition and forest floor dynamics in a common garden. Ecology 87:2288-2297

Hothorn T, Bretz F, Westfall P (2008) Simultaneous inference in general parametric models. Biometrical J 50:346-363

Hothorn T, Bretz F, Westfall P, Heiberger RM, Schuetzenmeister A, Scheibe S (2013) multcomp: simultaneous inference in general parametric models. R package version 1.2-18. Foundation for Statistical Computing, Vienna, Austria

Howard MM, Bell TH, Kao-Kniffin J (2017) Soil microbiome transfer method affects microbiome composition, including dominant microorganisms, in a novel environment. FEMS Microbiol Lett. https://doi.org/10.1093/femsle/ fnx092

Keiser AD, Keiser DA, Strickland MS, Bradford MA (2014) Disentangling the mechanisms underlying functional differences among decomposer communities. J Ecol 102:603-609

Kuiters A (1990) Role of phenolic substances from decomposing forest litter in plant-soil interactions. Acta Bot Neerl 39:329-348

Li Y, Bezemer TM, Yang J, Lü X, Li X, Liang W, Han X, Li Q (2019) Changes in litter quality induced by $\mathrm{N}$ deposition alter soil microbial communities. Soil Biol Biochem 130:33-42

Lundberg DS, Lebeis SL, Paredes SH, Yourstone S, Gehring J, Malfatti S, Tremblay J, Engelbrektson A, Kunin V, Rio TGD, Edgar RC, Eickhorst T, Ley RE, Hugenholtz P, Tringe SG, Dangl JL (2012) Defining the core Arabidopsis thaliana root microbiome. Nature 488:86-90

Mahan C, Sullivan KL, Black B, Kim KC, Yahner RH (2004) Overstory tree composition of eastern hemlock stands threatened by the hemlock woolly adelgid at Delaware Water Gap National Recreation Area. Castanea 69:30-38

Malik RJ (2019) No "Gadgil effect": temperate tree roots and soil lithology are effective predictors of wood decomposition. For Pathol 49:e12506 
Martin KJ, Rygiewicz PT (2005) Fungal-specific PCR primers developed for analysis of the ITS region of environmental DNA extracts. BMC Microbiol 5:28

Matulich KL, Martiny JB (2015) Microbial composition alters the response of litter decomposition to environmental change. Ecology 96:154-163

McCormack ML, Dickie IA, Eissenstat DM, Fahey TJ, Fernandez CW, Guo D, Helmisaari HS, Hobbie EA, Iversen CM, Jackson RB (2015) Redefining fine roots improves understanding of below-ground contributions to terrestrial biosphere processes. New Phytol 207:505-518

Melillo JM, Aber JD, Muratore JF (1982) Nitrogen and lignin control of hardwood leaf litter decomposition dynamics. Ecology 63:621-626

Mukhopadhyay S, Joy VC (2010) Influence of leaf litter types on microbial functions and nutrient status of soil: ecological suitability of forest trees for afforestation in tropical laterite wastelands. Soil Biol Biochem 42:2306-2315

Mullick DB (1977) The non-specific nature of defense in bark and wood during wounding, insect and pathogen attack. In: The structure, biosynthesis, and degradation of wood. Springer, Boston

Nippgen F, McGlynn BL, Marshall LA, Emanuel RE (2011) Landscape structure and climate influences on hydrologic response. Water Resour Res. https://doi.org/10.1029/ 2011WR011161

Notaguchi M, Okamoto S (2015) Dynamics of long-distance signaling via plant vascular tissues. Front Plant Sci 6:161

Oksanen J, Blanchet FG, Kindt R, Legendre P, Minchin PR, O'hara R, Simpson GL, Solymos P, Stevens MHH, Wagner H (2013) Package ‘vegan'. Community ecology package, version, 2

Paine CET, Stahl C, Courtois EA, Patiño S, Sarmiento C, Baraloto C (2010) Functional explanations for variation in bark thickness in tropical rain forest trees. Funct Ecol 24:1202-1210

Palozzi JE, Lindo Z (2018) Are leaf litter and microbes team players? Interpreting home-field advantage decomposition dynamics. Soil Biol Biochem 124:189-198

Parada AE, Needham DM, Fuhrman JA (2016) Every base matters: assessing small subunit rRNA primers for marine microbiomes with mock communities, time series and global field samples. Environ Microbiol 18:1403-1414

Pearce R (1996) Antimicrobial defences in the wood of living trees. New Phytol 132:203-233

Peng K, Jin L, Niu YD, Huang Q, Mcallister TA, Yang HE, Denise H, Xu Z, Acharya S, Wang S, Wang Y (2018) Condensed tannins affect bacterial and fungal microbiomes and mycotoxin production during ensiling and upon aerobic exposure. Appl Environ Microbiol 84:e02274-e2317

Perez G, Aubert M, Decaëns T, Trap J, Chauvat M (2013) Home-field advantage: a matter of interaction between litter biochemistry and decomposer biota. Soil Biol Biochem 67:245-254

Pointing SB, Parungao MM, Hyde KD (2003) Production of wood-decay enzymes, mass loss and lignin solubilization in wood by tropical Xylariaceae. Mycol Res 107:231-235

Posada RH, Madriñan S, Rivera E-L (2012) Relationships between the litter colonization by saprotrophic and arbuscular mycorrhizal fungi with depth in a tropical forest. Fungal Biol 116:747-755

Pyle C, Brown MM (1998) A rapid system of decay classification for hardwood logs of the eastern deciduous forest floor. J Torrey Bot Soc 125:237-245

Pylro VS, Roesch LFW, Morais DK, Clark IM, Hirsch PR, Tótola MR (2014) Data analysis for $16 \mathrm{~S}$ microbial profiling from different benchtop sequencing platforms. J Microbiol Methods 107:30-37

Read D, Perez-Moreno J (2003) Mycorrhizas and nutrient cycling in ecosystems - a journey towards relevance? New Phytol 157:475-492

Rognes T, Flouri T, Nichols B, Quince C, Mahé F (2016) VSEARCH: a versatile open source tool for metagenomics. PeerJ 4:e2584

Rosell JA (2016) Bark thickness across the angiosperms: more than just fire. New Phytol 211:90-102

Rosell JA, Castorena M, Laws CA, Westoby M (2015) Bark ecology of twigs vs. main stems: functional traits across eighty-five species of angiosperms. Oecologia 178:1033-1043

Schloss PD, Westcott SL, Ryabin T, Hall JR, Hartmann M, Hollister EB, Lesniewski RA, Oakley BB, Parks DH, Robinson CJ (2009) Introducing mothur: open-source, platform-independent, community-supported software for describing and comparing microbial communities. Appl Environ Microbiol 75:7537-7541

Shah F, Nicolás C, Bentzer J, Ellström M, Smits M, Rineau F, Canbäck B, Floudas D, Carleer R, Lackner G (2016) Ectomycorrhizal fungi decompose soil organic matter using oxidative mechanisms adapted from saprotrophic ancestors. New Phytol 209:1705-1719

Shorohova E, Kapitsa E (2014) Mineralization and fragmentation rates of bark attached to logs in a northern boreal forest. For Ecol Manag 315:185-190

Shorohova E, Ignatyeva O, Kapitsa E, Kauhanen H, Kuznetsov A, Vanha-Majamaa I (2012) Stump decomposition rates after clear-felling with and without prescribed burning in southern and northern boreal forests in Finland. For Ecol Manag 263:74-84

Sinsabaugh RL, Shah JJF (2011) Ecoenzymatic stoichiometry of recalcitrant organic matter decomposition: the growth rate hypothesis in reverse. Biogeochemistry 102:31-43

Strickland MS, Lauber C, Fierer N, Bradford MA (2009) Testing the functional significance of microbial community composition. Ecology 90:441-451

Sulman BN, Brzostek ER, Medici C, Shevliakova E, Menge DN, Phillips RP (2017) Feedbacks between plant N demand and rhizosphere priming depend on type of mycorrhizal association. Ecol Lett 20:1043-1053

Sun Y, Zhao S (2016) Leaf litter decomposition in urban forests: test of the home-field advantage hypothesis. Ann For Sci 73:1063-1072

Swift MJ, Heal OW, Anderson JM, Anderson J (1979) Decomposition in terrestrial ecosystems. University of California Press, Berkeley

The World Almanac for Kids. State tree Eastern hemlock, Anon, Pennsylvania. https://wak.infobaselearning.com/displaymedia.aspx ?wid $=104680 \% 26 \mathrm{mid}=10119$. Accessed 20 May 2020 
The World Almanac for Kids. State tree White oak, Anon, Maryland. https://wak.infobaselearning.com/displaymedia. aspx ? wid $=104680 \% 26 \mathrm{mid}=10029$. Accessed 20 May 2020

Treseder KK, Lennon JT (2015) Fungal traits that drive ecosystem dynamics on land. Microbiol Mol Biol Rev 79:243-262

Updegraff DM, Grant W (1975) Microbial utilization of Pinus radiata bark. Appl Environ Microbiol 30:722-726

Veen G, Freschet GT, Ordonez A, Wardle DA (2015) Litter quality and environmental controls of home-field advantage effects on litter decomposition. Oikos 124:187-195

Veen G, Keiser AD, van der Putten WH, Wardle DA (2018) Variation in home-field advantage and ability in leaf litter decomposition across successional gradients. Funct Ecol 32:1563-1574

Waldrop MP, Firestone MK (2004) Microbial community utilization of recalcitrant and simple carbon compounds: impact of oak-woodland plant communities. Oecologia 138:275-284

Wall DH, Moore JC (1999) Interactions underground: soil biodiversity, mutualism, and ecosystem processes. Bioscience 49:109-117

Wang Q, Zhong M, He T (2013) Home-field advantage of litter decomposition and nitrogen release in forest ecosystems. Biol Fertil Soils 49:427-434

Wei H, Xu Q, Taylor LE II, Baker JO, Tucker MP, Ding S-Y (2009) Natural paradigms of plant cell wall degradation. Curr Opin Biotechnol 20:330-338
White T, Brantley S, Banwart S, Chorover J, Dietrich W, Derry L, Lohse K, Anderson S, Aufdendkampe A, Bales R (2015) The role of critical zone observatories in critical zone science. In: Developments in earth surface processes. Elsevier, Amsterdam

Wu C, Zhang Z, Wang H, Huang G, Shu C, Kong F, Zhang Y, Wang GG, Liu Y (2019) Home-field advantage of CWD decomposition in subtropical forests varied by field sites. For Ecol Manag 444:127-137

Yates et al (submitted) Tree-induced alterations to soil properties and root-associated microorganisms following 23 years in a common garden. Plant Soil

Zas R, Moreira X, Sampedro L (2011) Tolerance and induced resistance in a native and an exotic pine species: relevant traits for invasion ecology. J Ecol 99:1316-1326

Zeng Q, Liu Y, An S (2017) Impact of litter quantity on the soil bacteria community during the decomposition of Quercus wutaishanica litter. PeerJ 5:e3777

Zhang Q-F, Laanbroek HJ (2018) The effects of condensed tannins derived from senescing Rhizophora mangle leaves on carbon, nitrogen and phosphorus mineralization in a Distichlis spicata salt marsh soil. Plant Soil 433:37-53

Zhu J, Pan X (2010) Woody biomass pretreatment for cellulosic ethanol production: technology and energy consumption evaluation. Bioresour Technol 101:4992-5002

Publisher's Note Springer Nature remains neutral with regard to jurisdictional claims in published maps and institutional affiliations. 